Jurnal Ekonomi dan Industri

Volume 20, No. 1, Januari-April 2019

p-ISSN : 0853-5248

\title{
PENGARUH KUALITAS PRODUK DAN KUALITAS LAYANAN TERHADAP KEPUASAN NASABAH BANK RAKYAT INDONESIA CABANG JAKARTA SUNTER
}

\author{
Nino Nopriandi Saleh*) \\ *) Dosen Program Studi Manajemen FE UNKRIS \\ Alamat: Kampus UNKRIS, Jatiwaringin Jakarta Timur \\ Email: nopriandinino@gmail.com
}

\begin{abstract}
This research aims to obtain both factual and conceptual information about the effect of product quality and service quality on customer satisfaction at the Jakarta Branch BRI (Bank Rakyat Indonesia) Sunter. This research used observation or survey technique by using a questionnaire to measure customer's satisfaction. The sampling method used Probability Sampling with participation of 100 customers as the respondents. The results of this research are simultaneous, both product quality and service quality do have a positive, relatively strong and significant effect on customer satisfaction by $62 \%$. The remaining $38 \%$ are influenced by other variables outside the model. Partially the product quality has a strong and positive effect on customer satisfaction by $57 \%$ while partially the service quality has a strong, positive, and significant effect on satisfaction by $59 \%$.
\end{abstract}

Keywords: Quality product, service quality, customer satisfaction

\section{PENDAHULUAN}

Bank sebagai lembaga perantara keuangan, disamping harus tetap menjaga kepercayaan masyarakat dengan menjamin tingkat likuiditas juga harus beroperasi secara efektif dan efisien untuk mencapai tingkat rentabilitas (keuntungan) yang memadai. Kunci dari keberhasilan bank adalah bagaimana bank tersebut bisa merebut hati masyarakat sehingga peranannya sebagai financial intermediary (perantara keuangan) berjalan dengan baik (Sinungan, 2000). Salah satu hal yang bisa merebut hati masyarakat adalah adanya kepuasan nasabah bank yang baik. Bagi nasabah, mengetahui kepuasan nasabah suatu bank dapat membantu mengambil keputusan apakan bank tersebut dapat dipercaya atau tidak (Arasli, 2005).

Bisnis perbankan merupakan bisnis jasa yang berdasarkan pada azas kepercayaan sehingga masalah kualitas layanan menjadi faktor yang sangat menentukan dalam keberhasilan usaha. Kualitas layanan merupakan suatu bentuk penilaian konsumen terhadap tingkat layanan yang diterima (perceived service) dengan tingkat layanan yang diharapkan (expected service) (Kotler, 2000). Nasabah membentuk suatu harapan akan nilai dan bertindak berdasarkan hal itu. Tingkat persepsi tentang kualitas layanan (nilai) yang tinggi akan menghasilkan kepuasan nasabah. Dengan pengukuran persepsi melalui atribut-atribut yang melekat pada suatu produk tabungan, maka dapat diketahui apakah persepsi konsumen bersifat positif atau negatif terhadap produk tabungan.

Tujuan utama perusahaan adalah tercapainya kepuasan konsumen, karena kepuasan konsumen merupakan investasi jangka panjang yang menguntungkan bagi kelangsungan hidup perusahaan. Membangun kepuasan konsumen merupakan inti dari profitabilitas jangka panjang. Konsumen yang puas dengan hasil kerja perusahaan akan menguntungkan bagi perusahaan. Agar dapat menciptakan kepuasan konsumen (dalam hal ini nasabah), maka perusahaan (bank) harus mengenali dan memahami kebutuhan konsumen (nasabah). 
Bank dapat dikategorikan sebagai perusahaan jasa dimana kualitas pelayanan memegang peranan penting dari kualitas produk itu sendiri. Tidak peduli sebesar apa atau seramai apapun, bank harus mampu mempertahankan kepuasan nasabah dan berorientasi pada kualitas pelayanan. Fenomena tersebut menjadikan pihak manajemen perlu meningkatkan cara atau strategi untuk menarik konsumen dalam memutuskan untuk menabung. Peningkatan jumlah nasabah disebabkan karena strategi yang diterapkan Bank BRI Cabang Jakarta Sunter cukup maksimal dalam menghimpun atau menarik nasabah.

Dalam rangka menghargai loyalitas nasabah Bank BRI memberikan hadiah yang rutin kepada nasabahnya (BRITAMA), selain itu dalam mengembangkan produk dan jasa yang ditawarkan, Bank BRI selalu mempertimbangkan kebutuhan nasabah yang selalu berubah. Lebih jauh lagi, Bank BRI terus menyempurnakan setiap produk atau jasa dengan menambahkan berbagai fitur baru untuk meningkatkan kenyamanan nasabah dalam menggunakannya serta memperbanyak fasilitas yang di sediakan di ATM, BRI Internet banking, BRI Phone Plus, BRI SMS Banking dan sebagainya. Dengan semakin pentingnya kualitas produk dan kualitas pelayanan yang diterapkan pada perusahaan, maka pihak manajemen dapat meningkatkan kepuasan nasabah.

\section{LANDASAN TEORI}

\section{Kualitas Produk}

Giddens (2002) yang menyatakan bahwa loyalitas pada merk timbul karena konsumen mempersepsikan merk tersebut menghasilkan produk yang memiliki sejumlah manfaat dan kualitas dengan harga yang sesuai. Hal ini juga didukung oleh Sciffman dan Kanuk (2004) yang menyebutkan salah satu faktor-faktor yang mempengaruhi terciptanya loyalitas merk adalah: perceived product superiority (persepsi/kesan/penerimaan keunggulan produk).

Devinisi perceive quality menurut Kotler (2000) dalam Simamora (2002) : kualitas adalah totalitas fitur dan karakteristik yang memampukan produk memuaskan kebutuhan yang dinyatakan maupun tidak dinyatakan.

Persepsi terhadap kualitas keseluruhan suatu produk atau jasa dapat menentukan nilai dari produk atau jasa tersebut dan berpengaruh langsung kepada keputusan pembelian konsumen dan loyalitas merka terhadap merk. Karena kesan kualitas merupakan persepsi konsumen, maka dapat dikatakan jika kesan kualitas konsumen positif berarti produk disukai, dan sebaliknya jika negative produk tidak disukai dan tidak akan bertahan lama di pasar.

Dalam konsep perceive quality menyoroti kualitas yang berdasarkan pada persepsi konsumen secara khusus dan yang terpenting adalah dimata konsumen. Bahkan banyak pemasar yang berkeyakinan bahwa persepsi adalah kualitas.

Produk dapat diartikan sebagai segala sesuatu yang dapat ditawarkan untuk memuaskan suatu kebutuhan dan keinginan (Kotler, 1997). Suatu produk dapat mencakup barang fisik, jasa, orang, tempat, organisasi dan gagasan. Terdapat lima tingkat produk yang membentuk suatu hirarki nilai bagi pelanggan.

Produk merupakan segala sesuatu yang dapat ditawarkan produsen untuk diperhatikan, diminta, dicari, dibeli, digunakan atau dikonsumsi pasar sebagai pemenuhan kebutuhan atau keinginan pasar yang bersangkutan (Handi Irawan (2004). Menurut Rampersad:2001 produk meliputi: kualitas, kuantitas, merk, label, bentuk, mode, jaminan, pelayanan, dan pembungkus.

Bauran produk yang berupa kualitas, kuantitas, label, bentuk, mode, jaminan, pelayanan, dan pembungkus sudah menjadi standar yang dapat dengan mudah ditiru dan 
dimiliki pesaing, sementara satu-satunya atribut yang sulit ditiru adalah merk, khususnya citra yang telah terekam dalam benak konsumen. Perang pemasaran kini menjadi perang antar merk, suatu persaingan demi dominasi merk. Berbagai perusahaan dan investor menyadari merk sebagai aset perusahaan paling bernilai. Satu-satunya cara untuk menguasai pasar adalah memiliki pasar dengan merk yang dominan atau memiliki ekuitas merk yang kuat.

Menurut American Marketing Association (Kotler, 2000) merk adalah nama, istilah, marketer, simbol rancangan, atau kombinasi yang dapat mengidentifikasikan barang atau jasa dari seorang atau sekelompok penjual agar dapat membedakan produk tersebut dari produk pesaing. Merk memberi sejumlah keuntungan pada produsen maupun konsumen. Simamora (2002) menyebutkan dengan adanya merk, masyarakat mendapat jaminan tentang mutu suatu produk yaitu dengan memperoleh informasi yang berkaitan dengan merk tersebut. Dikenalnya merk oleh masyarakat membuat pihak perusahaan meningkatkan inovasi produk untuk menghadapi persaingan. Dalam konsep perceive quality menyoroti kualitas yang berdasarkan pada persepsi konsumen secara khusus, yang terpenting adalah dimata konsumen.

Kualitas produk sebagai driver dari kepuasan pelanggan sudah lama diyakini. Setidaknya, lebih lama dibandingkan dengan keyakinan terhadap kualitas pelayanan sebagai driver kepuasan pelanggan. Kualitas produk adalah driver kepuasan pelanggan yang multidimensi. Bagi konsumen, kualitas mempunyai beberapa dimensi. Paling tidak terdapat 5 dimensi dari kualitas produk yang perlu diperhatikan oleh setiap produsen yang ingin mengejar kepuasan pelanggan terhadap kualitas produk.

Menurut Irawan (2007), konsumen akan memiliki persepsi yang baik, jika konsumen beranggapan bahwa produk tersebut berkualitas baik. Kualitas produk ini adalah dimensi yang global yang terdiri dari beberapa yaitu; performance (kinerjalfungsional produk), durability (keawetan), feature (fitur), coformance (kesamaan standar/konsistensi).

Dimensi pertama adalah performance. Ini adalah dimensi yang paling basic dan berhubungan dengan fungsi utama dari suatu produk. Konsumen akan sangat kecewa apabila harapan mereka terhadap dimensi ini kurang terpenuhi. Siapa yang Tidak kecewa saat membeli AC jika ternyata kurang dingin?

Dimensi kualitas produk yang kedua adalah reliability. Dimensi performance dan reliability sepintas terlihat mirip tetapi mempunyai perbedaan yang jelas. Reliability lebih menunjukkan probabilitas produk gagal menjalankan fungsinya. Produk pompa air dikatakan mempunyai performance yang baik apabila dia mampu bekerja sesuai dengan kapasitas atau daya semprot seperti yang dijanjikan. Pompa tersebut dikatakan sebagai pompa yang mempunyai reliability yang baik apabila tidak pernah ngadat atau macet selama pemakaian.

Dimensi kualitas yang ketiga adalah feature atau fitur. Dimensi ini dapat dikatakan sebagai aspek sekunder. Karena perkembangan fitur ini hampir tidak ada batasnya sejalan dengan perkembangan teknologi, maka fitur menjadi target para produsen utnuk berinovasi dalam upaya memuaskan pelanggan. Hal kedua yang perlu dicatat dalam dimensi fitur ini adalah kenyataan bahwa kepuasan pelanggan terhadap fitur selalu dimediasi dengan harga. Hampir selalu terjadi bahwa penambahan fitur selalu mengakibatkan kenaikan harga dari produk tersebut. Apa yang menyebabkan perbandingan harga antar Nokia yang berseri 3,6,8 atau 9? Setiap seri, mempunyai fitur yang berbeda.

Dimensi yang keempat adalah durability atau keawetan menunjukkan suatu pengukuran terhadap siklus produk, baik secara teknis maupun waktu. Produk tersebut dikatakan awet kalau sudah banyak digunakan atau sudah lama sekali digunakan. Yang pertama adalah awet secara teknis. Awet secara teknis contohnya adalah oli pelumas yang 
mengatakan bahwa produknya awet karena bisa digunakan hingga $10.000 \mathrm{~km}$, lebih awet dari oli lain yang perlu diganti apabila sudah dipakai hingga jarak $3.000-5.000 \mathrm{~km}$.

Dimensi yang kelima adalah conformance. Dimensi ini menunjukkan seberapa jauh suatu produk dapat menyamai standar atau spesifikasi tertentu. Produk yang mempunyai conformance tinggi, berarti produknya sesuai dengan standar yang telah ditentukan. Salah satu aspek dari conformance adalah konsistensi.

\section{Kualitas Layanan}

Sampai saat ini belum terdapat definisi kata kualitas yang diterima secara umum dan menyeluruh. Pengertian kualitas dapat pula dibedakan menurut pandangan produsen dan konsumen. Definisi kualitas menurut produsen adalah kesesuaian terhadap spesifikasi, dimana produsen memberikan toleransi tertentu yang dispesifikasikan untuk dimensidimensi kritis dan tiap bagian yang dihasilkan. Pada bidang jasa, kualitas dipertahankan dengan memenuhi standar pelayanan. Dari sudut pandang konsumen, kualitas berarti nilai yaitu seberapa baik suatu produk atau jasa menyajikan tujuan yang dimaksudkan dengan tingkat harga yang bersedia dibayar oleh konsumen.

Menurut Kotler (2002) definisi pelayanan adalah setiap tindakan atau kegiatan yang dapat ditawarkan oleh suatu pihak kepada pihak lain, yang pada dasarnya tidak berwujud dan tidak mengakibatkan kepemilikan apapun. Produksinya dapat dikaitkan atau tidak dikaitkan pada satu produk fisik. Pelayanan merupakan perilaku produsen dalam rangka memenuhi kebutuhan dan keinginan konsumen demi tercapainya kepuasan pada konsumen itu sendiri. Kotler juga mengatakan bahwa perilaku tersebut dapat terjadi pada saat, sebelum dan sesudah terjadinya transaksi.

Pada umumnya pelayanan yang bertaraf tinggi akan menghasilkan kepuasan yang tinggi serta pembelian ulang yang lebih sering. Menurut Lovelock (dalam Tjiptono, 2001) mengemukakan bahwa kualitas pelayanan merupakan tingkatan kondisi baik buruknya sajian yang diberikan oleh perusahaan jasa dalam rangka memuaskan konsumen dengan cara memberikan atau menyampaikan jasa yang melebihi harapan konsumen. Jadi penilaian konsumen terhadap kualitas pelayanan merupakan refleksi persepsi evaluatif terhadap pelayanan yang diterimanya pada waktu tertentu.

Kualitas, dalam organisasi jasa tertentu bukanlah sesuatu yang mudah didefinisikan, karena hal tersebut sangat berhubungan erat dengan pandangan konsumen. Secara umum dikatakan bahwa kualitas adalah karakteristik produk / jasa, yang ditentukan oleh pemakai dan diperoleh melalui pengukuran proses serta melalui perbaikan yang berkelanjutan.

Menurut Parasuraman, Zeithaml, dan Berry (dalam Umar, 2003), untuk mengevaluasi kualitas jasa pelanggan umumnya menggunakan 5 dimensi adalah sebagai berikut : 1). Tangibles merupakan bukti nyata dari kepedulian dan perhatian yang diberikan oleh penyedia jasa kepada konsumen. Pentingnya dimensi tangibles ini akan menumbuhkan image penyedia jasa terutama bagi konsumen baru dalam mengevaluasi kualitas jasa. Perusahaan yang tidak memperhatikan fasilitas fisiknya akan menumbuhkan kebingungan atau bahkan merusak image perusahaan. 2). Reliability atau keandalan merupakan kemampuan perusahaan untuk melaksanakan jasa sesuai dengan apa yang telah dijanjikan secara tepat waktu. Pentingnya dimensi ini adalah kepuasan konsumen akan menurun bila jasa yang diberikan tidak sesuai dengan yang dijanjikan. Jadi komponen atau unsur dimensi reliability ini merupakan kemampuan perusahaan dalam menyampaikan jasa secara tepat dan pembebanan biaya secara tepat. 3). Responsiveness atau daya tanggap merupakan kemampuan perusahaan yang dilakukan oleh langsung karyawan untuk memberikan pelayanan dengan cepat dan tanggap.Daya tanggap dapat menumbuhkan persepsi yang positif terhadap kualitas iasa yang diberikan. Termasuk didalamnya jika 
terjadi kegagalan atau keterlambatan dalam penyampaian jasa, pihak penyedia jasa berusaha memperbaiki atau meminimalkan kerugian konsumen dengan segera. 4). Assurance atau jaminan merupakan pengetahuan dan perilaku emploiyee untuk membangun kepercayaan dan keyakinan pada diri konsumen dalam mengkonsumsi jasa yang ditawarkan. Dimensi ini sangat penting karena melibatkan persepsi konsumen terhadap resiko ketidakpastian yang tinggi terhadap kemampauan penyedia jasa. Perusahaan membangun kepercayaan dan kesetiaan konsumen melalui karyawan yang terlibat langsung menangani konsumen. Jadi komponen dari dimensi initerdiri dari kompetensi karyawan yang meliputi ketrampilan, pengetahuan yang dimiliki karyawan untuk melakukan pelayanan dan kredibilitas perusahaan yang meliputi hal-hal yang berhubungan dengan kepercayaan konsumen kepada perusahaan seperti, reputasi perusahaan, prestasi dan lain-lain. 5). Emphaty merupakan kemampuan perusahaan yang dilakukan langsung oleh karyawan untuk memberikan perhatian kepada konsumen secara individu, termasuk juga kepekaan akan kebutuhan konsumen. Jadi komponen dari dimensi ini merupakan gabungan dari akses yaitu kemudahan untuk memanfaatkan jasa yang ditawarkan oleh perusahaan, komunikasi merupakan kemampuan melakukan untuk menyampaikan informasi kepada konsumen atau memperoleh masukan dari konsumen dan pemahaman merupakan usaha untuk mengetahui dan memahami kebutuhan dan keinginan konsumen.

\section{Kepuasan Pelanggan}

Mencapai tingkat kepuasan pelanggan tertinggi adalah tujuan utama pemasaran. Pada kenyataannya, akhir-akhir ini banyak perhatian tercurah pada konsep kepuasan "total," yang implikasinya adalah mencapai kepuasan sebagian saja tidaklah cukup untuk membuat pelanggan setia dan kembali lagi. Ketika pelanggan merasa puas akan pelayanan yang didapatkan pada saat proses transaksi dan juga puas akan barang atau jasa yang mereka dapatkan, besar kemungkinan mereka akan kembali lagi dan melakukan pembelianpembelian yang lain dan juga akan merekomendasikan pada teman-teman dan keluarganya tentang perusahaan tersebut dan produk-produknya. Juga kecil kemungkinannya mereka berpaling ke pesaing-pesaing perusahaan. Mempertahankan kepuasan pelanggan dari waktu ke waktu akan membina hubungan yang baik dengan pelanggan. Hal ini dapat meningkatkan keuntungan perusahaan dalam jangka panjang.

Lebih jauh lagi Tse and Wilson (1988) menguraikan dua variabel utama yang menentukan kepuasan pelanggan, yaitu expectations dan perceived performance. Apabila perceived performance melebihi expectations maka pelanggan akan puas, tetapi apabila sebaliknya maka pelanggan merasa tidak puas. Kotler and Keller (2006), menyatakan bahwa kepuasan pelanggan adalah perasaan senang atau kekecewaan seseorang setelah membandingkan kinerja atau hasil yang dirasakan dibandingkan dengan harapannya. Dari beberapa uraian tersebut dapat diketahui bahwa kepuasan konsumen dihasilkan dari proses perbandingan antara kinerja yang dirasakan dengan harapannya, yang menghasilkan disconfirmation paradigm.

Fornell et al. (1996) dalam temuannya menyebutkan bahwa (1) kepuasan konsumen secara menyeluruh adalah hasil evaluasi dari pengalaman konsumsi sekarang yang berasal dari keandalan dan standarisasi pelayanan; (2) kepuasan konsumen secara menyeluruh adalah hasil perbandingan tingkat kepuasan dari usaha yang sejenis, dan (3) bahwa kepuasan konsumen secara menyeluruh diukur berdasarkan pengalaman dengan indikator harapan secara keseluruhan, harapan yang berhubungan dengan kebiasaan, dan harapan yang berhubungan dengan keterandalan jasa tersebut. Oliver and De Sarbo (1988) memandang tingkat kepuasan (satisfaction) timbul karena adanya suatu transaksi khusus 
antara produsen dengan konsumen yang merupakan kondisi psikologis yang dihasilkan ketika faktor emosi mendorong harapan (expectations) dan disesuaikan dengan pengalaman mengkonsumsi sebelumnya (perception).

Selain itu menurut Zeithaml et al. (1996) kepuasan pelanggan merupakan perbandingan antara layanan yang diharapkan (expectations) dengan kinerja (perceived performnce) Selain teori expectacy disconfirmation model yang sudah dikenal, masih ada beberapa teori tentang kepuasan yakni equity theory dan atribution theory.

Para peneliti menyatakan bahwa atribut yang mempengaruhi kepuasan pelanggan disesuaikan dengan produknya. Misalnya, untuk produk mobil, atribut yang dipertimbangkan seperti, reliabilitas, serviceability, prestise, durability, functionality, dan mudah digunakan. Sementara untuk makanan yang dipertimbangkan misalnya rasa, kesegaran, aroma dan sebagainya ( Zeithaml and Bitner, 2003).

\section{METODE PENELITIAN}

\section{Desain Penelitian}

Penelitian ini menggunakan pendekatan Explanatory analysis. Artinya setiap variabel yang diketengahkan pada hipotesis akan diamati melalui pengujian hubungan kausal antara variabel Independent terhadap variabel Dependent. Dalam hal ini mengkaji hubungan antara dua variabel atau lebih, dimana dalam penelitian ini mengkaji hubungan dan pengaruh antara faktor - faktor kualitas produk dan kualitas layanan terhadap kepuasan nasabah Bank BRI Cabang Jakarta

\section{Populasi dan Sampel}

Populasi adalah wilayah generalisasi yang terdiri atas ; obyek/ subyek yang mempunyai kuantitas dan karakteristik tertentu yang ditetapkan oleh peneliti untuk dipelajari dan kemudian ditarik kesimpulannya (Sugiyono, 2005). Populasi dalam penelitian ini adalah pelanggan Bank BRI Cabang Jakarta Sunter yang memanfaatkan produk jasa simpanan dalam bentuk tabungan dengan mata uang rupiah pada tahun 2010 sebanyak 48.754 nasabah di Bank BRI Cabang Jakarta Sunter. Sampel adalah sebagian dari jumlah karakteristik yang dimiliki oleh populasi tersebut (Sugiyono, 2005). Besaran sampel penelitian adalah orang yang diambilkan dari jumlah nasabah pengguna tabungan (saving deposits) dengan mata uang rupiah sebanyak 100 orang.

\section{HASIL PENELITIAN DAN PEMBAHASAN}

\section{Uji Validitas}

Pengujian validitas ini dilakukan untuk menguji apakah tiap-tiap butir pernyataan telah mewakili indikator yang akan diselidiki. Menurut Masrum yang dikutip oleh Sugiyono (2001) menyatakan bahwa biasanya syarat minimum untuk dianggap valid adalah $r=0.300$. Jadi apabila korelasi antar butir-butir dengan skor total kurang dari 0.300 maka butir dalam instrumen tersebut dinyatakan tidak valid. Uji validitas dilakukan dengan melihat korelasi antar skor masing-masing item pertanyaan dengan skor total. Dari hasil penghitungan koefisien korelasi skor tiap butir pernyataan instrument kualitas produk dari 100 responden. Jumlah pernyataan masing-masing variabel 8 pernyataan dengan total skor setiap responden diperoleh hasil disajikan dalam tabel sebagai berikut : 
Tabel - 1 : Hasil Uji Validitas Instrumen Variabel

\begin{tabular}{|c|c|c|c|c|c|}
\hline \multirow[b]{2}{*}{ Pernyataan } & \multicolumn{3}{|c|}{ r hitung } & \multirow[b]{2}{*}{ r Kritis } & \multirow[b]{2}{*}{ Kesimpulan } \\
\hline & Kualitas Produk & Kualitas Layanan & Kepuasan Nasabah & & \\
\hline Ins. 1 & 0.721 & 0.876 & 0.741 & 0.300 & Valid \\
\hline Ins. 2 & 0.723 & 0.843 & 0.784 & 0.300 & Valid \\
\hline Ins. 3 & 0.7797 & 0.797 & 0.86 & 0.300 & Valid \\
\hline Ins. 4 & 0.768 & 0.794 & 0.887 & 0.300 & Valid \\
\hline Ins. 5 & 0.787 & 0.848 & 0.766 & 0.300 & Valid \\
\hline Ins. 6 & 0.738 & 0.802 & 0.7 & 0.300 & Valid \\
\hline Ins. 7 & 0.709 & 0.816 & 0.809 & 0.300 & Valid \\
\hline Ins. 8 & 0.723 & 0.847 & 0.865 & 0.300 & Valid \\
\hline Ins. 9 & & 0.81 & 0.837 & 0.300 & Valid \\
\hline Ins. 10 & & 0.834 & 0.757 & 0.300 & Valid \\
\hline
\end{tabular}

Sumber : Hasil Olah Data Penelitian

Berdasarkan tabel 1 dapat dilihat dan disimpulkan bahwa dari semua butir pernyataan variabel kualitas produk, kualitas layanan dan kepuasan nasabah hasilnya adalah valid.

\section{Uji Reliabilitas}

Selanjutnya dilakukan uji reliabilitas untuk mengetahui sejauh mana hasil pengukurannya dapat diandalkan dan konsisten. Pada tabel 2 hasil pengujian berikut diketahui bahwa semua variabel mempunyai alpha di atas 0.6 yang berarti bahwa semua variabel dalam penelitian ini dapat diandalkan.

Tabel-2 : Hasil Uji Reliabilitas Variabel

\begin{tabular}{ccc}
\hline Variabel & Cronbach's Alpha & Keterangan \\
\hline Kualitas Produk & $\mathbf{0 . 7 6 6}$ & Reliabel \\
Kualitas Layanan & $\mathbf{0 . 7 8 5}$ & Reliabel \\
Kepuasan Nasabah & $\mathbf{0 . 7 6 9}$ & Reliabel \\
\hline
\end{tabular}

Sumber : Hasil Olah Data Penelitian

Berdasarkan angka-angka reliabilitas cronbach alpha tersebut tampak bahwa seluruh pernyataan yang ada membentuk ukuran yang reliabel yaitu dari kualitas produk, kualitas layanan dan kepuasan nasabah membentuk ukuran yang reliabel dari masing-masing dimensi.

Tabel-3 : Pengaruh Kualitas Produk dan Kualitas Layanan Terhadap Kepuasan Nasabah

\begin{tabular}{lccccc}
\hline \multicolumn{1}{c}{ Hubungan Variabel } & \multicolumn{5}{c}{ Parameter } \\
\cline { 2 - 6 } \multicolumn{1}{c}{ R Square } & Konstanta & Koef. & Sig. & $\alpha$ \\
\hline Kualitas Produk & $\mathbf{0 , 6 2 1}$ & $\mathbf{7 , 2 9 3}$ & $\mathbf{0 , 3 3 2}$ & $\mathbf{0 , 0 0 0}$ & $\mathbf{0 , 0 5}$ \\
Kualitas Layanan & & & $\mathbf{0 , 4 6 0}$ & \\
\hline Pengujian Signifikansi & & & & \\
F Hitung $>$ F Tabel $=\mathbf{7 9 , 5 9 8}>\mathbf{3 , 0 8 8}$ & & & & \\
\hline
\end{tabular}

Keterangan : Variabel Y Kepuasan Nasabah

Sumber : Hasil Olah Data Penelitian

Berdasarkan hasil perhitungan tabel 3, maka dapat dijelaskan sebagai temuan pada penelitian adalah, bahwa secara langsung dan simultan (jamak) kualitas produk dan kualitas layanan berpengaruh positif terhadap kepuasan nasabah. Perhatikan temuan 
koefisiean penduga (undtandarized coefficiens beta), dimana variabel kualitas produk menghasilkan coeffisien $(+0,332)$ dan signifikansi untuk probability sig 0,002 atau signifikan untuk $\alpha=0,01$ dan variabel kualitas pelayanan $(+0,460)$ dan signifikansi untuk probality sig 0,000 atau signifikansi $\alpha=0,01$. Melalui penduga ini dapat digambarkan, bahwa kualitas layanan memberikan indikasi pengaruh yang relatif lebih tinggi dari pada kualitas produk. Pengaruh simultan tersebut, diprediksikan untuk penduga constanta adalah positif sebesar 7,923 dengan probability sig $(0,011)$ untuk $\alpha=0,05$. Artinya secara simultan kedua variabel prediktor tersebut memberikan dampak fluktuatif yang linier terhadap kepuasan nasabah dengan tingkat signifikansi yang sangat baik.

Lebih lanjut dapat dijelaskan, bahwa secara simultan $\mathrm{R}$-Square $=0,621$, artinya kondisi ini juga mampu menjelaskan bahwa kualitas produk dan kualitas layanan secara jamak memberikan kontribusi sebesar $62,1 \%$, dan sisanya atau sebesar $37,9 \%$ disumbangkan oleh variabel lain di luar model.

Tabel-4 : Pengaruh Kualitas Produk Terhadap Kepuasan Nasabah

\begin{tabular}{lccccc}
\hline & \multicolumn{5}{c}{ Parameter } \\
\cline { 2 - 6 } \multicolumn{1}{c}{ Hubungan Variabel } & R Square & Konstanta & Koef. & Sig. & $\alpha$ \\
\hline Kualitas Produk & $\mathbf{0 . 5 7 1}$ & $\mathbf{2 2 . 9 9 7}$ & $\mathbf{0 . 5 8 4}$ & $\mathbf{0 , 0 0 0}$ & $\mathbf{0 , 0 5}$ \\
\hline Pengujian Signifikansi & & & & & \\
T Hitung $>$ T Tabel $=3.911>\mathbf{0 . 1 5 9 8}$ & & & & & \\
\hline
\end{tabular}

Keterangan : Variabel Y Kepuasan Nasabah

Sumber : Hasil Olah Data Penelitian

Model Prediksi $\mathrm{Y}=22,997+0,584 \mathrm{X}_{1}+\mathrm{e}$

Memperhatikan tampilan pada tabel 4 di atas, maka dapat dijelaskan sebagai temuan pada penelitian adalah, bahwa secara langsung dan parsial (sendiri) kualitas produk berpengaruh positif terhadap Kepuasan nasabah. Perhatikan temuan koefisiean penduga (Undtandarized Coefficiens Beta), dimana variabel kualitas produk menghasilkan coeffisien $(+0,584)$ dan signifikansi untuk probability sig 0,000 atau signifikan untuk $\alpha=$ 0,01 . Melalui penduga ini dapat digambarkan, bahwa Kualitas produk memberikan indikasi pengaruh yang positif. Pengaruh parsial tersebut, diprediksikan untuk penduga Constanta adalah positif sebesar 22,997 dengan probability sig $(0,000)$ untuk $\alpha=0,01$. Artinya secara parsial variabel prediktor tersebut memberikan dampak fluktuatif yang linier terhadap kepuasan nasabah dengan tingkat signifikansi yang sangat baik.

Lebih lanjut dapat dijelaskan, (R-Square $=0,571$, artinya kondisi ini mampu menjelaskan bahwa kualitas produk secara parsial memberikan kontribusi sebesar 57,1\% terhadap kepuasan nasabah, sedangkan sisanya sebesar $42.9 \%$ disumbangkan faktor lain.

Tabel-5 : Pengaruh Kualitas Layanan Terhadap Kepuasan Nasabah

\begin{tabular}{lccccc}
\hline \multirow{2}{*}{ Hubungan Variabel } & \multicolumn{5}{c}{ Parameter } \\
\cline { 2 - 6 } Kualitas Produk & R Square & Konstanta & Koef. & Sig. & $\alpha$ \\
\hline Pengujian Signifikansi & $\mathbf{0 . 5 9 1}$ & $\mathbf{1 0 . 4 0 9}$ & $\mathbf{0 . 6 9 8}$ & $\mathbf{0 , 0 0 0}$ & $\mathbf{0 , 0 5}$ \\
T Hitung $>$ T Tabel $=\mathbf{1 2 . 5 2 1}>\mathbf{0 . 1 5 9 8}$ & & & & & \\
\hline
\end{tabular}

Keterangan : Variabel Y Kepuasan Nasabah

Sumber : Hasil Olah Data Penelitian

Model Predikasi $=\mathrm{Y}=10,409+0,698 \mathrm{X} 2+\mathrm{e}$ 
Memperhatikan tampilan pada tabel 5, maka dapat dijelaskan sebagai temuan pada penelitian adalah, bahwa secara langsung dan parsial (sendiri) kualitas pelayanan berpengaruh positif terhadap kepuasan nasabah. Perhatikan temuan koefisien penduga (Undtandarized Coefficiens Beta), dimana variabel kualitas layanan menghasilkan coeffisien $(+0,698)$ dan signifikansi untuk probability sig 0,000 atau signifikan untuk $\alpha=$ 0,01 . Melalui penduga ini dapat digambarkan, bahwa kualitas pelayanan memberikan indikasi pengaruh yang positif. Pengaruh parsial tersebut, diprediksikan untuk penduga Constanta adalah positif sebesar 10,409 dengan probabilitiy sig $(0,000)$ untu $\alpha=0,01$. Artinya secara parsial variabel prediktor (kualitas layanan) tersebut memberikan dampak fluktuatif yang linier terhadap kepuasan nasabah dengan tingkat signifikansi yang sangat baik.

Lebih lanjut dapat dijelaskan, $R$-Square $=0,591$, artinya kondisi ini mampu menjelaskan bahwa kualitas layanan secara parsial memberikan kontribusi sebesar 59,1\% terhadap kepuasan nasabah, sedangkan sisanya sebsesar 40,9\% disumbangkan faktor lain.

\section{KESIMPULAN DAN SARAN}

\section{Kesimpulan}

Dari hasil analisis dan pembahasan pada penelitian ini dapat disimpulkan melalui uji statistik dapat ditarik kesimpulan bahwa kualitas produk dan kualitas layanan berpengaruh positif, dan signifikan terhadap kepuasan nasabah. Baik secara bersama-sama maupun secara parsial.

\section{Saran}

Berdasarkan analisis dan pembahasan pengujian secara empiris suatu kesimpulan yang dikemukakan di atas, pada sub bagian ini, penulis mencoba memberikan rekomendasi atau saran-saran yang mungkin dapat ditindaklanjuti, yaitu sebagai berikut. Semua variabel mempunyai pengaruh positif terhadap kepuasan nasabah sehingga Bank BRI Cabang Jakarta Sunter perlu memperhatikan lebih khusus variable kualitas produk dan kualitas pelayanan tersebut serta mencari terobosan yang dapat meningkatkan kepuasan pelanggan misalnya program kredit dengan plafond tinggi tapi bungan ringan. Sikap tanggap karyawan dan perhatian dalam kualitas pelayanan perorangan maupun kelompok merupakan unsur yang sangat menentukan dalam pelayanan perbankkan. Untuk itu, sudah selayaknya para karyawan meningkatkan sikap tanggap perhatiannya terhadap nasabah dalam sistem layanan yang diberikan sehingga dapat bersaing dengan pihak perbankan sejenis.

\section{DAFTAR PUSTAKA}

Kotler and Keller . 2006. Total Quality Management. Yogyakarta : Andi Offset Aaker. 1991. Marketing. (3rd ed.). Boston: Homewood.

Afrizal. 2006. Pengaruh kualitas pelayanan terhadap kepuasan nasabah kredit bank BTN Pusat di Bekasi Program Pasca Sarjana Magister Manajemen Universitas Krisnadwipayana. Jakarta

Al Rasyid. Harun. 1998. Teknik Penarikan Sampel dan Penyusunan Skala. Bandung: Program Pascasarjana Universitas Padjadjaran

Arasli. H. 2005. Penilaian Pelaksanaan Pekerjaan dan Pengembangan Karyawan. Yogyakarta: BPFE. 
Arikunto. 2002. Manajemen Pemasaran. : Analisa. Perencanaan. Implikasi dan Kontrol. Jilid I. PT Prenhallindo. Jakarta.

Cleland dan Bruno (dalam Simamora). 2002. Marketing Services. New York: The Free Press.

Engel et al. 1990. The Service Quality-Loyalty relationship in retail services: does commitment matter?' Journal of Retaining and ConsumerServices. 12. pp. 99-111

Fornell et al. 1996. Pengaruh Kualitas Jasa Terhadap Loyalitas Pelanggan. Wacana Jurnal Ilmu-ilmu Sosial. (Online).Vol. 2. No. 2. (digilib.brawijaya.ac.id. diakses 22 Januari 2007).

Gaspersz. V. 1997. Manajemen Kualitas dalam Industri Jasa. Jakarta : PT Gramedia

Ghozali. 2005. Statistik (Teori dan Aplikasi) Edisi ke lima. Jakarta : Erlangga.

Giddens. 2002. Strategi Pemasaran. Andi Offset. Yogyakarta.

Handi Irawan. 2004. Manajemen Kualitas dalam Industri Jasa. Jakarta : PT Gramedia

Kotler \& Armstrong. 2001. Pengaruh Kualitas Jasa Terhadap Loyalitas Pelanggan. Wacana Jurnal Ilmu-ilmu Sosial. (Online).Vol. 2. No. 2. (digilib.brawijaya.ac.id. diakses 22 Januari 2007).

Kotler. 1997. Total Quality Service. Edisi Pertama. Yogyakarta : Andi Offset.

—, 2000. Marketing Management. twelfth edition. New Jersey: Pearson Education. Inc. 2002. Manajemen Pemasaran. Jakarta: PT Prenhalindo.

Kutner H. Michael. 2005. Sample Survey Methode and Theory. Vol. I. New York: John Willey \& Sons. Inc.

Loly Yunita. 2008. Analisis Pengaruh Produk Dan Kualitas Pelayanan Terhadap Kepuasan Nasabah Tabungan Britama BRI. Program Pasca Sarjana Magister Manajemen Universitas Krisnadwipayana. Jakarta

Lovelock (dalam Tjiptono. 2001). Service Marketing and Management. New Jersey:Prentice Hall.

Oliver and De Sarbo. 1988. Business Research Methods. $5^{\text {th }}$ edition. Chicago: Richard D. Irwin Inc.

Parasuraman. Zeithaml. dan Berry (dalam Umar). 2003. Kepuasan dan Kesetiaan Pelanggan. Jakarta:Erlangga.

Philip Kotler. 2000. Strategic Marketing for Educational Institutions. 2nd edition. Prentice Hall. New Jersey.

Rampersad. 2001 The Service Quality-Loyalty relationship in retail services: does commitment matter?' Journal of Retaining and ConsumerServices. 12. pp. 99-111

Sciffman dan Kanuk. 2004. Total Quality Service. Edisi Pertama. Yogyakarta : Andi Offset.

Setiaji. 2004. Statistika terapan untuk penelitian. Alfabeta. Bandung.

Simamora. 2002. Manajemen Sumber Daya Manusia. Edisi ke-III. STIE YKPN. Yogyakarta.

Singarimbun. 1998. Metode Penelitian Survei. Jakarta LP3ES.

Sinungan. 2000. Penilaian Pelaksanaan Pekerjaan dan Pengembangan Karyawan. Yogyakarta: BPFE

Slovin. 2000. Sampling: A Quick Reliable Guide to Practical Statistics. New Yoek: Simon and Schuster.

Spreng et al. 1996. Marketing Services. New York: The Free Press.

Stanton. 2002. Perilaku Konsumen. Yogyakarta: AMUS Yogyakarta dan CV. Ngeksigondo Utama 
Sugiyono. 2001. Metode Bisnis. Alfabeta. Bandung

— , 2005 Metode Penelitian Bisnis. Alfabeta. Bandung

Tjiptono Fandi. 1996. Total Quality. Edisi Pertama. Yogyakarta : Andi Offset

Tjiptono Fandi. 2001. Riset Pemasaran dan Aplikasi dengan SPSS. Jakarta. PT Elex Media Komputindo , 2007. Prinsip-prinsip Total Quality Service (TQS). Yogyakarta: ANDI.

Tse and Wilson. 1988. Relationship Marketing. Jakarta: PT Gramedia Pustaka

Weiner. 1971. Customer Relationship Marketing: A Strategic Imperative in the World of e.Business. Canada: John Wiley \& Sons Ltd. Burnham T.A.. J.K. Frels. and V. Mahajan. 2003. "Consumer Switching

Zeithaml and Bitner. 2003. Customer Loyalty How To earn it. How To Keep It I. Mc Graw Hill. Kentucky. 